\title{
New neoliberal public housing policies: between centrality discourse and peripheralization practices in Santiago, Chile
}

Rodrigo Hidalgo Dattwyler, Luis Daniel Santana Rivas e Felipe Link

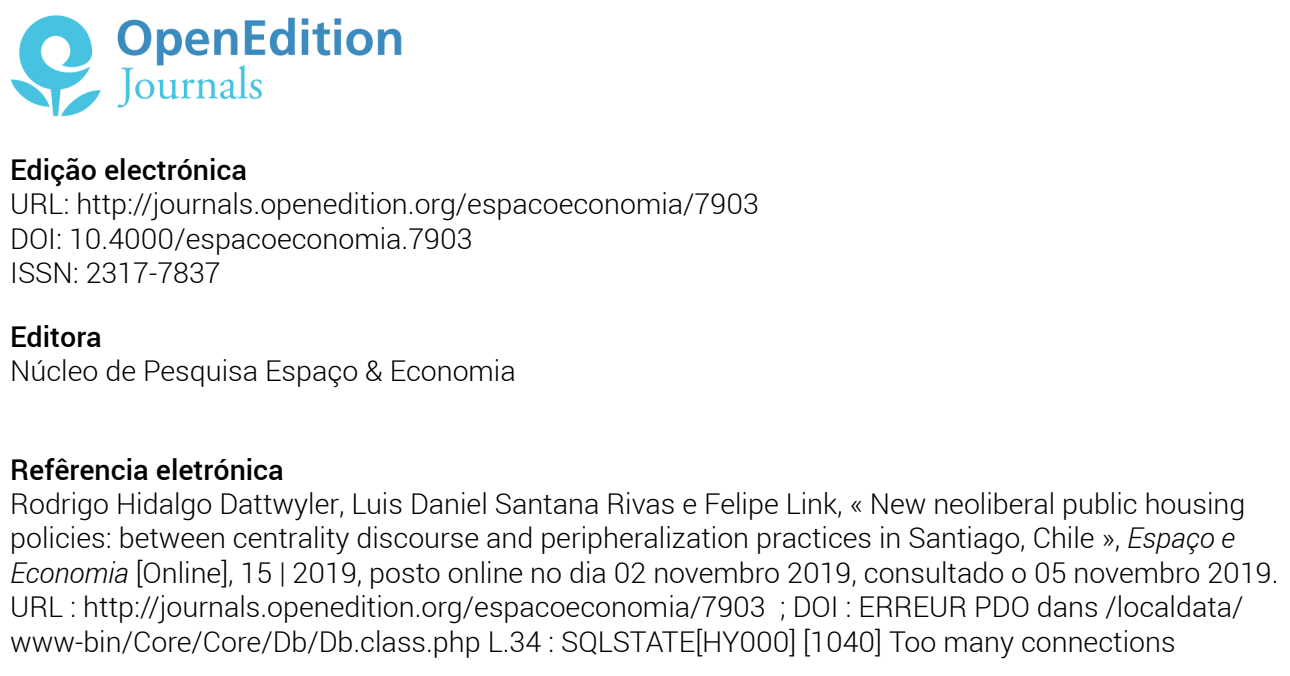

Este documento foi criado de forma automática no dia 5 novembro 2019.

(c) NUPEE 
New neoliberal public housing policies: between centrality discourse and peripheralization practices in Santiago, Chile

Rodrigo Hidalgo Dattwyler, Luis Daniel Santana Rivas e Felipe Link 


\section{Periódico : Journal Housing Studies}

\section{Link para o artigo:}

1 https://www.tandfonline.com/doi/abs/10.1080/02673037.2018.1458287

\section{Abstract}

2 The lack of geographical equality in the development of neoliberal social housing models is evidence of differing ideological discourses and socio-spatial practices in the production of social housing. Based on a critical analysis of the Housing Policy for Quality Improvement and Social Integration promoted in Chile in 2006-the basis for a set of subsequent policies-this study seeks to identify the link between state discourse promoting further urban centralization of social housing and neoliberal subsidy allocation practices that have shaped the geography of recent residential production (2007-2012). Using an ideological critique and a descriptive spatial analysis to assess the notions of urban centrality, we found that equality and integration form the rhetoric used to legitimize and reproduce practices that lead to peripheralization of the poor. These practices are not limited to the city but have expanded to the extended urban area, creating a larger niche for the real estate industry.

3 Keywords: Housing policy, ideology, real estate, $\underline{\text { Chile }}$ 